\title{
DEVELOPMENT OF ANTIMICROBIAL \\ TEXTILES AND EVALUATION \\ OF THEIR ENERGY-INFORMATION IMPACT
}

\section{СТВОРЕННЯ АНТИМІКРОБНИХ \\ ТЕКСТИЛЬНИХ МАТЕРІАЛІВ ТА ОЦІНКА \\ ЇХ ЕНЕРГО-ІНФОРМАЦЙНОГО ВПЛИВУ}

\section{Natalia Sadretdinova ${ }^{1}$ \\ Sergey Bereznenko ${ }^{2}$}

DOI: https://doi.org/10.30525/978-9934-26-001-8-2-9

Abstract. A development in the field of improving human health and improving its vitality without the involvement of harmful synthetic and expensive pharmaceuticals is appropriate and promising for todays. The paper proposes a fundamentally new approach to clothing design, which will have a positive impact on the physical and emotional state of man simultaneously with its main functions.

Since garments come into contact with the human body 24 hours a day, it is advisable to use clothing with multifunctional aspect: protection from pathogenic microflora of internal and external origin, and to stimulate the vital functions of human organs and systems. Analysis of research in the field of functionalization of medical textiles shows that today different ways of giving antimicrobial properties to textile materials have been developed and successfully used. In the worsening global environmental crisis promising area of antimicrobial properties is the so-called "green technology", which involves the production of new products with minimal environmental damage. The use of herbal preparations in the creation of antibacterial treatments is due to its availability, as well as low toxicity, lack of addiction and negative effects, the possibility of long-term use by adults and children.

\footnotetext{
${ }^{1}$ Candidate of Technical Sciences, Associate Professor, Kyiv National University of Technologies and Design, Ukraine

${ }^{2}$ Candidate of Technical Sciences, Professor

Kyiv National University of Technologies and Design, Ukraine

(C) Natalia Sadretdinova, Sergey Bereznenko
} 
Given the scientific uncertainty and the emergence of more and more new data on the early signs of harm and the potential adverse health effects that may be associated with antimicrobial treatments, the precautionary approach seems to be most appropriate. There is a need to clarify information on the effect of physically or chemically modified materials on the human body. Previous studies have experimentally confirmed the presence of energy effects of textile materials on the human body. However, determination of the nature of the impact is a complex task, which solution depends on a number of factors, such as the raw material composition, its structure, surface characteristics, etc.

Considering these aspects, the purpose of the study was the functionalization of medical textiles by providing them with long-lasting antimicrobial properties based on "green technologies" and the study of their energy-information impact on the human body. The following tasks have been solved in the course of the study. The analysis of modern types and methods of textile modification is carried out; the prospects of use of "green technologies" are shown. Several samples of textile materials with antimicrobial properties, modified by herbal preparations, were obtained. It has been established that the medicinal materials obtained as a result of the modification of the peony solution exert a positive influence on the energy state of the person and activate processes in the body responsible for the immune system. This makes it possible to believe that these materials actively protect the body from exposure to pathogenic microflora. Also, the method of energy information diagnostics determines the resistance to washing achieved by the modification of the antimicrobial effect. After three cycles of washing, citric acid modified with peony solution exerts a more active effect on the organism of the subjects compared to those modified with only peony solution.

Therefore, the results obtained in this paper contribute to the spread of the use of "green technologies" for the manufacture of textile materials and clothes with antimicrobial properties.

\section{1. Вступ}

Зважаючи на особливості сучасного середовища споживання одягу, текстиль може виступати потенційним джерелом інфекції, утримуючи мікроорганізми та передаючи їх контактним особам чи поверхням. Це 
ми спостерігаємо в ситуації, що склалася у світі в зв'язку з пандемією, викликаною COVID 19, коли одним з важливих способів запобігання поширенню інфекції стали засоби індивідуального антимікробного захисту як для лікарів, так і для населення. Тому, як відповідь на виклик сучасності, наразі інтенсифікуються дослідження, пов'язані із антимікробними обробками (АМО).

Оскількишвейні вироби контактують зтіломлюдини 24годининадобу, доцільним є багатофункціональний аспект використання одягу: захист від патогенної мікрофлори внутрішнього і зовнішнього походження, та стимулювання життедіяльності органів та систем органів людини. Одяг повинен активно пригнічувати життєдіяльність мікроорганізмів, як за рахунок природних властивостей матеріалів, так і шляхом штучного введення в структуру чи на поверхню матеріалу біоактивних компонентів з антимікробними властивостями пролонгованої дії.

Встановлено, що одягові матеріали мають власний енергетичний потенціал і безпосередньо інформаційно впливають на енергетичний баланс організму людини. Особлива роль в формуванні енергоінформаційного потенціалу належить способу виготовлення, структурі, кольору та додатково наданим властивостям, в тому числі за рахунок обробки біоцидами. Використання рослинної сировини при створенні антибактеріальних препаратів обумовлене іiі доступністю, а також, в більшості випадків, низькою токсичністю, відсутністю звикання і негативних побічних явищ, можливістю довготривалого використання лікарських засобів дорослими і дітьми. Резистентність мікроорганізмів до фітопрепаратів виробляється повільніше, ніж до синтетичних лікарських засобів.

Зважаючи на зазначені аспекти, метою роботи стала функціоналізація текстильних матеріалів за рахунок надання їм довготривалих антимікробних властивостей на основі “зелених технологій” i дослідження їх енерго-інформаційного впливу на організм людини.

\section{2. Види біоцидних обробок}

Бактерії, мікрогриби і дріжджі живуть та розмножуються скрізь, де для цього $є$ відповідні умови: волога, живильне середовище (вуглеводи) і відповідна температура. Такі матеріали, як текстиль, шкіра, хутро являються сприятливим живильним середовищем для багатьох 
мікроорганізмів. Прояви їх надмірного зростання на текстильних виробах різноманітні і вкрай небажані: поряд з утворенням запаху, 3 появою цвілевих плям і зміною забарвлення вони можуть призвести до втрати функціональних властивостей матеріалу, наприклад, його еластичності чи розривної міцності. Для захисту текстильних матеріалів від зазначеного негативного впливу використовуються різні види спеціальних захисних обробок.

Під біоиидною обробкою на сьогоднішній день розуміють надання текстильним виробам антимікробних, антигрибкових, антигнилістних, репелентних властивостей $[1$, р. 24, 25].

В залежності від функціонального призначення розрізняють декілька видів біоцидних обробок.

Антимікробна (AMO), що перешкоджає розмноженню і росту на текстильному матеріалі колоній мікроорганізмів (бактерій, грибів, вірусів), і таким чином дозволяе виконувати функцію «захисного бар'єру» для шкіри людини від попадання на неї патогенних мікробів ззовні. В залежності від аспекту дії розрізняють декілька різновидів антимікробної обробки.

Протигрибкова (ПГО) - різновид АМО, але в ПГО основним завданням $є$ стримування росту грибів на текстильному матеріалі. У разі ПГО мова йде про профілактику грибкових захворювань шкіри людини.

Антигнилістна (АГО) - захищає текстильний матеріал при його контакті з землею і водою від мікроорганізмів, що викликають гниття волокна i, таким чином, руйнування матеріалу.

Протиалергенна (ПАТ) - перешкоджає розмноженню на текстильному матеріалі мікроскопічного пилового кліща (екскременти якого є алергенами) i, таким чином, виконує профілактичні функції.

Репелентна (РВ) - надає текстилю властивість відштовхувати кровососів - комах, які $\epsilon$ переносниками вірусних інфекційних захворювань.

Вимоги до біоцидів наступні [2, p. 170, 171]:

- ефективність проти найпоширеніших мікроорганізмів при мінімальній концентрації антибактеріальної речовини й максимальному строку іiї дії;

- гіпоалергенність та нетоксичність для людського організму використаних концентрацій біоциду; 
- відсутність кольору й запаху;

- невисока вартість біоциду, що не повинна призвести до значного удорожчання готового виробу з антибактеріальними властивостями;

- відсутність погіршення фізико-механічних, гігієнічних і інших властивостей текстильного матеріалу у зв'язку з модифікацією його біоцидними речовинами;

- поєднуваність із використовуваними препаратами для обробки матеріалів і текстильно-допоміжних речовин в процесі виробництва матеріалу;

- світлостійкість, атмосферостійкість.

Сфери використання антимікробних обробок різноманітні: одяг медперсоналу й хворих; лікарняна постільна білизна; захисний одяг армійського контингенту; захисний одяг, білизна, шкарпетки робочих гарячих дільниць і інших професій важкої фізичної праці; спортивний текстиль; текстиль для водних вправ та процедур; раневі покриття; імпланти.

\section{3. Аналіз способів надання текстильним матеріалам біоцидних властивостей}

Серед відомих способів надання текстильним матеріалам біоцидних властивостей можна виділити наступні групи:

- просочення бактерицидними препаратами, хімічна й фізична модифікація волокон для виробництва текстильного матеріалу;

- просочення текстильного матеріалу розчином бактерицидної речовини, хімічна модифікація матеріалу;

- введення біоцидів у полімероутворюючу речовину;

- додання біоцидних властивостей текстильним матеріалам на заключних стадіях фарбування й обробки;

- застосування біоцидних речовин при пранні або чищенні текстильних полотен і виробів.

Найбільшу ефективність мають хімічні методи, у процесі реалізації яких відбувається утворення хімічних зв'язків (наприклад, при введенні антибактеріальних препаратів у волоконоутворюючі розплави й розчини). Так, на стадії полімеризації при одержанні поліаміду додають антибактеріальний препарат, що представляє собою оловоорганічну сполуку (окис або гідроокис трибутилолова), що 
забезпечує збереження антибактеріального ефекту після багаторазових прань [3, p. 90]. В хімічних методах модифікації $є$ істотні технологічні, економічні й екологічні недоліки. Хімічна модифікація волокон може погіршити деякі властивості полімерних волокон. Окрім того, хімічна модифікація полімерних волокнистих матеріалів вимагає придбання, транспортування й монтажу додаткового устаткування й хімічних реагентів, що істотно ускладнює технологію, збільшує трудомісткість виробничого процесу, що може несприятливо позначитися на екологічній ситуації й призвести до подорожчання кінцевого продукту.

Додання антибактеріальних властивостей текстильним матеріалам методом просочення їх розчинами біоцидів є традиційним і перевіреним часом способом, однак речовини, застосовувані для просочення, можуть бути токсичні для людини та навколишнього середовища i довговічність не завжди велика.

Одним із способів підвищення довговічності біоцидних обробок на текстильних виробах є методи мікрокапсуляції. Біоциди поміщують у нанорозмірні контейнери (циклодекстрин, ліпосоми - везикули). Краплі або тверді частинки антибактеріальних речовин вивільняються та починають свою дію за певних умов (тертя, тиск, температура, розчинення оболонок капсул). У випадку везикул, патогенні бактерії, що мають спорідненість до везикул, атакують їх, руйнують мембрану везикули і 3 неї вивільняються молекули або наночастинки біоциду [4, p. 679-684].

Фінішна обробка текстилю гідрофобізуючими препаратами (наприклад, силіконами) може послабляти вплив мікроорганізмів на матеріали за рахунок зменшення кількості адсорбованої вологи, однак не призводить до повного їх усунення [5, p. 19-25].

В якості біоцидів досить широкого поширення набули полімерні сполуки 3 використанням наночасток металів. Використання солей міді в якості антибактеріального агенту призводить до фарбування текстильного матеріалу в жовто-зелений колір. Використання цинку обмежене їх слабкою біоцидною дією, а солей ртуті, олова, миш'яку підвищеною токсичністю для людини.

Активне використання нанопрепаратів срібла для просочення текстилю обумовлено їх значними й незаперечними перевагами перед всіма існуючими антимікробними засобами, оскільки сполуки срібла, маючи широкий спектр антимікробної активності, багато в 
чому позбавлені недоліків, пов'язаних із проблемою резистентності до них патогенних мікроорганізмів [7, р. 54]. Найбільш ефективні для знищення хвороботворних мікроорганізмів частинки срібла розміром менше 10 нм. Вони мають більшу питому площу поверхні, що збільшує область контакту срібла з бактеріями, значно поліпшуючи його бактерицидні дії. Таким чином, застосування срібла у вигляді наночастинок дозволяє в сотні разів знизити концентрацію срібла зі збереженням всіх бактерицидних властивостей [6, p. 49-54].

Отже, срібнаобробкатканинидозволяєнадативиробамантимікробні, антивірусні, гіпоалергенні, антиоксидантні, імуностимулюючі властивості зі збереженням ефекту від двох тижнів до кількох місяців, але тут також виникають проблеми, такі як вимивання іонів у стічні води, що призводить до забруднення навколишнього середовища.

В умовах загострення глобальної екологічної кризи, іншим перспективним напрямом надання антимікробних властивостей $\epsilon$, так звані, “зелені технології”, що передбачають виробництво нових видів продукції з мінімальною шкодою для навколишнього середовища. Так, для одержання захисних антимікробних виробів використовують матеріали на основі луб'яних волокон, унікальні природні властивості яких можуть доповнюватись чи підсилюватись за рахунок поверхневої модифікації [8, p. 22-31]. Природні барвники та пігменти, отримані 3 рослин, комах, тварин та мінералів, також виявляють протимікробну дію. Екстракти та витяжки з рослин можуть використовуватись у вигляді відновників при наномодифікації, а також самостійно, у вигляді просочень чи напилень.

Медицині здавна відомі антибактеріальні та противірусні властивості рослинної сировини. Препарати на їх основі використовуються в стоматології (парадонтоз, гінгівіт, інфекційнозапальних захворюваннях ротової порожнини Сангвіритрин, Дентос, Ерамін.); дерматології (посконник конопляний, настойки софори, арніки, каланхое та ін.); при захворюванях глотки і при застуді (тонзиліт препарати Тонзилгон, Амцарін, Флакозід, Хелепін); тощо.

Ряд лікарських трав також має противірусну дію. Наприклад, при ГРВІ застосовується Альтабор - противірусний препарат проти застуди, який одержують з екстракту суплідь сірої і чорної (клейкої) вільхи. На основі щучки дернистої і війника наземного виробляється 
препарат Протефлазід, що використовується в лікуванні та профілактиці простудних захворювань. Німецький препарат Імупрет має противірусну та імуномодулюючу дію. Противірусні властивості він має завдяки наявності у складі хвоща польового, листя горіха волоського і кори дуба.

Достеменно невідомо, які саме речовини обумовлюють антибактеріальну дію: встановлені тільки групи сполук, такі як флавоноїди, фенолкарбонові кислоти, алкалоїди, фенольні сполуки і т.д.

Як бачимо, сучасна наука пропонує велику кількість варіантів надання антимікробних властивостей текстильним матеріалам. Враховуючи наукову невизначеність і появу нових даних про ранні ознаки шкоди і можливі несприятливі наслідки для здоров'я людини, які можуть бути пов'язані з АМО, обережний підхід видається найбільш доцільним. Виникає необхідність уточнення інформації про вплив фізично чи хімічно модифікованих матеріалів на організм людини. Адже мова йде про вироби медичного призначення, експлуатація яких пов'язана з багатьма факторами ризику, і тому важливо розуміти, яким чином наявність тієї чи іншої обробки впливатиме на загальний стан організму потенційного споживача таких виробів у традиційному середовищі функціонування.

\section{4. Оцінка впливу текстильних матеріалів, модифікованих рослинними препаратами, на функціональний стан організму людини}

Сьогодні у сфері медичної діагностики все більшого поширення набуває енергоінформаційна хвильова медицина, основні положення якої базуються на на квантовій механіці та теоретичній фізиці. Відомі біля 20 способів і приладів, в яких використовуються різні фізичні ефекти: електропунктурна діагностика, терапія електромагнітними хвилями міліметрового діапазону з залученням інших видів енергії (УФ-випромінювань, торсійних полів), комп’ютерні варіанти електропунктурної діагностики, СКЕНАР-терапія, мінерало-, кольорово-звукова і спектральна терапія тощо.

Попередні дослідження [9, р. 59-65], проведені з використанням методів електрохвильової діагностики, виявили комплексний вплив матеріалів і їх компонентів на функціональний стан органів і систем 
органів. Це свідчить про суттєву роль матеріалів для виготовлення одягу, як важливих засобів захисту людини від агресивного навколишнього середовища, патогенних факторів внутрішнього i зовнішнього походження. При цьому інформаційно-хвильовий характер взаємодії елементів системи «людина - одяг - мікробне середовище» може бути реалізований за рахунок стоячих хвиль, які виникають при інтерференції біжучої хвилі від хвороботворного організму і зустрічної хвилі, відбитої від матеріалу. Таким чином, проведення порівняльного аналізу результатів реєстрації функціонального стану організму людини під впливом досліджуваного текстильного матеріалу та без його впливу, дає можливість оцінити ступінь безпечності використання цього матеріалу для функціонування організму потенційних споживачів у виробничому середовищі.

\section{1 Характеристика предмету досліджень}

Огляд літературних джерел показав, що наразі основним матеріалом, що використовується для виготовлення медичного одягу, є сумішеві текстильні полотна із вмістом бавовни. Тому в якості текстильної основи для нанесення модифікуючого перепарату було обрано бавовняну тканину (65 ПЕ / 35 бавовна) полотняного переплетення 3 поверхневою густиною $125 \Gamma / \mathrm{M}^{2}$.

В якості антимікробного препарату, що застосовується для модифікації текстильного полотна, застосовано розчин настойки півонії лікарської, яка запатентована як антимікробний лікарський засіб та чинить активний вплив на грам-позитивні і грам-негативні бактерії та гриби, такі як Staphylococcus aureus, Candida albicans, Синегнійна паличка та Bacillus subtilis [10]. Рекомендована концентрація розчину 0,05 г/л.

\section{2 Методика та пристрої для нанесення антимікробного покриття}

Традиційні антимікробні покриття, в основному, можна розглядати як полімерні матриці. Вони зазвичай наносяться на текстильний матеріал за допомогою розпилення чи просочення розчином з наступним процесом сушіння для видалення розчинника. Загальною проблемою для таких антимікробних покриттів $\epsilon$ нестійкість до багаторазових мокрих обробок, яка може бути викликана обмеженою адгезією. 
Для порівняння стійкості доданих в результаті модифікування антимікробних властивостей текстильного матеріалу застосовувались два способи нанесення модифікатора на текстильний матеріал.

Для надання антимікробної обробки першим способом по поверхні досліджуваного зразка тканини розпилюють водний нанорозчин 3 настоянкою півонії лікарської за допомогою парової щітки.

Другий спосіб передбачає просочення текстильного матеріалу лимонною кислотою та наступне розпилення нанорозчину півонії лікарської. Для попереднього просочення текстилю була використана лимонна кислота (2-гідрокси-1,2,3-пропантрикарбонова кислота, $\left.\mathrm{C}_{6} \mathrm{H}_{8} \mathrm{O}_{7}\right)$ HOOC-CH2-C(OH)COOH-CH2-COOH 3 робочою концентрацією 0,96 г/л. Суть модифікування полягає в створенні необхідних умов для реакції між ангідридом модифікуючого агента (кислоти) і бавовняної целюлози текстильного матеріалу. Для цього тканину заливають розчином лимонної кислоти заданої концентрації. Після перемішування протягом 30 хв. при $20^{\circ} \mathrm{C}$, розчин кислоти зливають, тканину поміщають в посудину і піддають сушці при $50^{\circ} \mathrm{C}$ в сушильній шафі протягом 4 годин. Після сушіння, термохімічна реакція між кислотою і целюлозою відбувається за рахунок підвищення температури до $120^{\circ} \mathrm{C}$, при якому кислота переходить в ангідрид. Час обробки становить 2 години. Після охолодження продукти реакції промивають дистильованою водою до нейтральної реакції, щоб видалити надлишок кислоти. Після висушування розпилюють водний розчин з рослинного препарату - півонії лікарської концентрацією нанорозчину 0,05 г/л за допомогою парової щітки Philips GC361/20 Steam \& Go повторюючи метод 1.

Для висушування зразків тканини використовувалась сушильна шафа ШС-3, яка забезпечує сушку матеріалів при заданій температурі (на $10^{\circ} \mathrm{C}$ вище кімнатної та до $+200^{\circ} \mathrm{C}$ ).

Розпилення здійснювалось за допомогою парової щітки для одягу Philips GC361/20 Steam \& Go побутового призначення, яка використовується для безпечного прасування всіх видів тканин, 3 постійною подачею пари 22г/хв [11].

Для перевірки стійкості отриманого антимікробного ефекту проводилось прання зразків в автоматичній пральній машині згідно методики ГОСТ ISO 6330-2011. 


\section{3 Методика оцінки енерго-інформаційного впливу}

На сьогодні науковцями [12-14] доведене важливе значення біологічно активних точок та біологічно активних зон в сприйнятті впливів факторів зовнішнього середовища, зокрема метеорологічних, сонячної активності, різноманітних електромагнітних полів тощо. I ці досягнення вже використовуються у створенні новітнього функціонального одягу.

Попередні дослідження, проведені у співпраці 3 науковцями Хмельницького національного університету, показали, що за допомогою апаратно-програмного діагностичного комплексу (АПДК) «InteraDiaCor» (Реєстр медичної техніки України № 3277/2004 від 30.10.2009 р.) можнареєструватипараметризональноїелектропровідностізапостійним струмом від біологічно активних ділянок тіла, які функціонально пов'язані із органами, і оцінювати функціональний стан останніх та організму в цілому на клітинному рівні [15].

Дослідження проведено за методикою, викладеною у роботі [9]. Згідно з методикою після двох повних циклів діагностування здійснено порівняння результатів діагностики функціонального стану органів та систем організму людини без впливу досліджуваного трикотажного полотна та із ним. При цьому на екрані монітору ПК порівнювали гістограми, що відображають три основні стани органів та систем організму людини: енергетичну лабільність (стан норми), енергетичну нестійкість (нестабільність енергетичних процесі в органі) та енергетичну недостатність (пригніченість енергетичних процесів).

Згідно розробленої методики рівень негативного та позитивного енергетично-хвильового впливу запропоновано оцінювати за числовим значенням коефіцієнту комфортності Кк:

$$
\kappa \kappa=\frac{K c-K H}{K c} \cdot 100 \%
$$

де $K_{H}$ - кількість органів (систем органів) організму людини, у функціональному та енергетичному стані яких відбулися негативні зміни, спричинені впливом матеріалу;

Kc - кількість органів (систем органів) організму людини, що діагностувалися.

Методика проведення досліджень комфортності на АПДК «InteraDiaCor» описана в [15] та запатентована [16]. 


\section{5. Оцінка впливу оброблених рослинними препаратами текстильних матеріалів на енергетичний та функціональний стан органів і систем органів людини}

Для виявлення впливу модифікованого текстильного матеріалу на людський організм проведено дослідження функціонального стану організму людини 3 використанням АПДК «Intera-DiaCor». Дослідження виконано із залученням двох осіб молодшої вікової групи, функціональний стан організму яких на момент проведення дослідження не мав значних відхилень від норми. Така кількість досліджуваних є достатньою, оскільки визначення функціонального стану організму людини за допомогою АПДК «Intera-DiaCor» має високу точність (відносна гарантійна помилка не перевищує 5 \%).

Дослідження проводились у чотирьох середовищах взаємодії людини (досліджуваної особи) з текстильним матеріалом:

C1 - людина без зразка матеріалу;

С2 - людина з немодифікованим зразком матеріалу;

С3 - людина зі зразком, модифікованим шляхом розпилення водного розчину півонії лікарської (перший спосіб);

C4 - людина зі зразком, модифікованим шляхом просочення текстильного матеріалу лимонною кислотою та наступного розпилення нанорозчину півонії лікарської (другий спосіб).

Після двох повних циклів діагностування здійснювали порівняння результатів діагностики функціонального стану органів та систем організму людини без впливу досліджуваного полотна та із ним. Приклади отриманих гістограм приведені на рисунку 1.

На основі отриманих гістограм підраховано сумарну кількість органів та систем органів організму людини, що знаходяться у різних енергетичних станах: енергетичної лабільності (зелені стовпці), енергетичної нестійкості (червоні стовпці) та енергетичної недостатності (блакитні стовпці) без впливу матеріалу та під їх впливом на досліджуваних осіб. На основі цих даних за формулою, приведеною вище, розраховано коефіцієнт комфортності. Результати узагальнені в таблиці 1.

Як видно з таблиці, немодифікований зразок матеріалу (C2) чинить незначний вплив на функціональний стан організму, завдяки чому його можна важати інертним щодо впливу на організм. В той же час, 
Chapter «Engineering sciences»
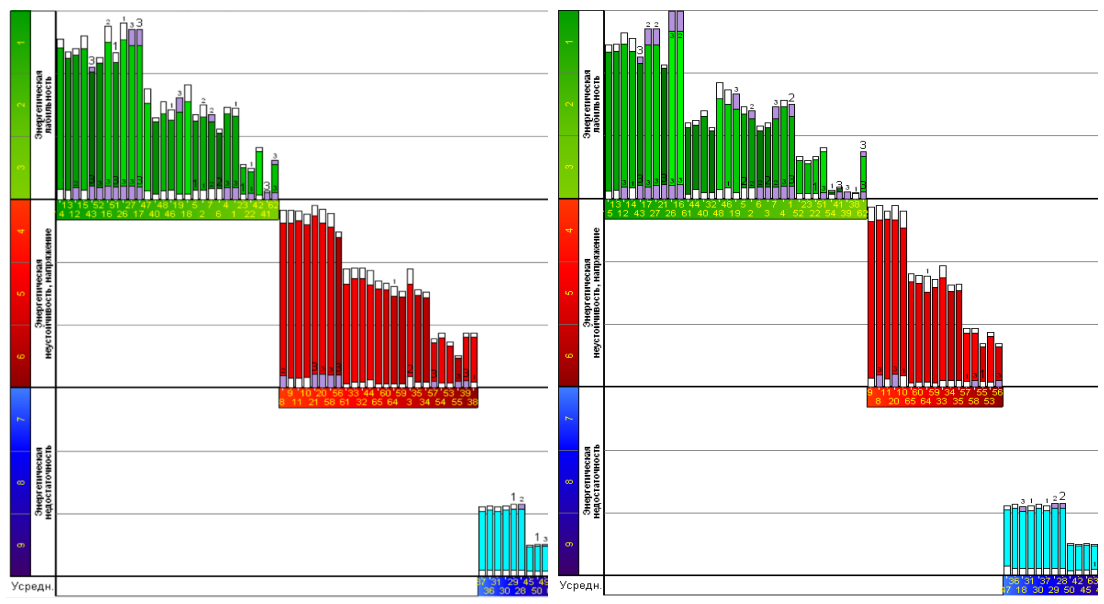

a) $\mathrm{C} 1$

б) $\mathrm{C} 2$
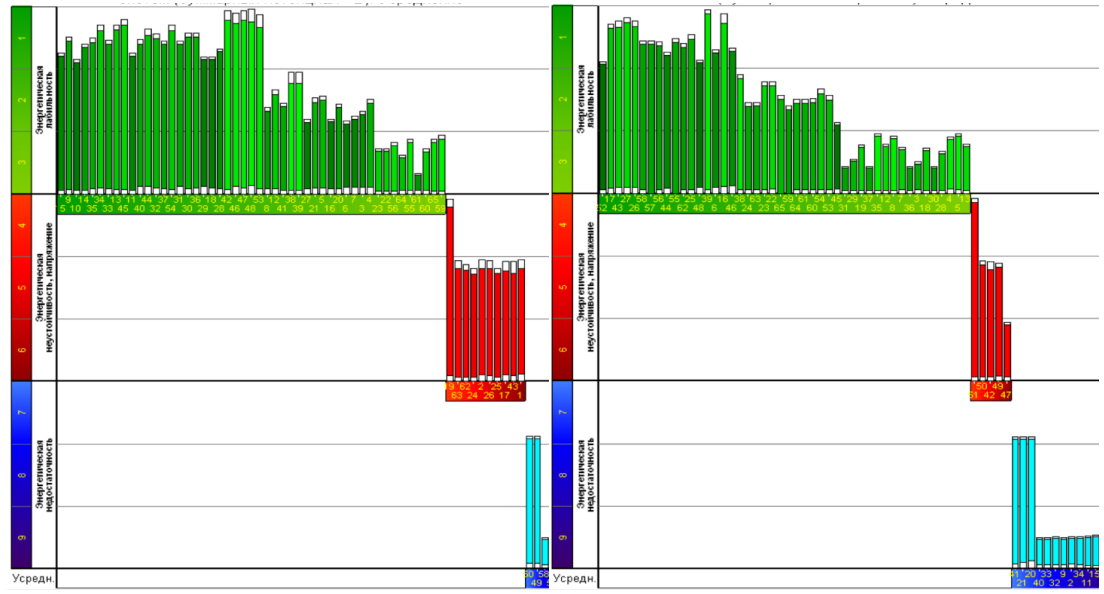

в) $\mathrm{C} 3$

г) $\mathrm{C} 4$

Рис. 1. Гістограми енергетичного та функціонального стану органів: a - людини без зразка матеріалу, C1;

б - людини з немодифікованим зразком матеріалу, С2; в - людини зі зразком, модифікованим першим способом, C3; г - людини зі зразком, модифікованим другим способом, С4. 


\section{Таблиця 1}

\section{Результати розрахунку рівня енергоінформаційного впливу текстильних матеріалів з АМО на функціональний стан організму людини}

\begin{tabular}{|c|c|c|c|c|c|c|c|c|}
\hline \multirow{3}{*}{$\begin{array}{c}\text { Види } \\
\text { середовищ } \\
\text { випробо- } \\
\text { вування }\end{array}$} & \multicolumn{6}{|c|}{$\begin{array}{c}\text { Кількість органів людини, } \\
\text { що знаходяться у стані: }\end{array}$} & \multirow{2}{*}{\multicolumn{2}{|c|}{$\begin{array}{c}\text { Коефіцієнт } \\
\text { комфортност }\end{array}$}} \\
\hline & \multicolumn{2}{|c|}{$\begin{array}{l}\text { енергетичної } \\
\text { лабільності }\end{array}$} & \multicolumn{2}{|c|}{$\begin{array}{c}\text { енергетичної } \\
\text { нестійкості }\end{array}$} & \multicolumn{2}{|c|}{$\begin{array}{l}\text { енергетичної } \\
\text { недостатності }\end{array}$} & & \\
\hline & $\begin{array}{c}\text { особа } \\
1\end{array}$ & $\begin{array}{c}\text { особа } \\
2\end{array}$ & $\begin{array}{c}\text { особа } \\
1\end{array}$ & $\begin{array}{c}\text { особа } \\
2\end{array}$ & $\begin{array}{c}\text { особа } \\
1\end{array}$ & $\begin{array}{c}\text { особа } \\
2\end{array}$ & $\begin{array}{c}\text { особа } \\
1\end{array}$ & $\begin{array}{c}\text { особа } \\
2\end{array}$ \\
\hline $\mathrm{C} 1$ & 28 & 37 & 25 & 0 & 12 & 28 & 1,00 & 1,00 \\
\hline $\mathrm{C} 2$ & 33 & 37 & 17 & 0 & 15 & 28 & 1,08 & 1,00 \\
\hline C3 & 49 & 47 & 10 & 2 & 6 & 16 & 1,32 & 1,15 \\
\hline $\mathrm{C} 4$ & 46 & 60 & 5 & 5 & 14 & 0 & 1,28 & 1,35 \\
\hline
\end{tabular}

зразки, модифіковані нанорозчином півонії лікарської, нанесеним першим та другим способами (C3, C4), чинять істотний вплив на взаємовідношення кількості органів у різних енергетичних станах. При цьому спостерігається тенденція до збільшення кількості органів у стані енергетичної лабільності, та зменшення їх кількості у станах енергетичної нестійкості та недостатності.

Для визначення стійкості AMO до впливу експлуатаційних навантажень, аналогічні дослідження проведено для зразків модифікованих матеріалів після трьох циклів прання. Результати приведені в таблиці 2.

Незначне зменшення показників лабільності вказує на те, що отриманий в результаті модифікації тканини розчиномпівоніїлікарської позитивний ефект щодо впливу на енергетично-функціональний стан організму, є досить стійким до впливу прання. Після трьох циклів прання зразки, модифіковані лимонною кислотою з розчином півонії (C4) чинять більш активну дію на організм досліджуваних осіб, в порівнянні із зразками модифікованими лише розчином півонії (C3). Це можна пояснити тим, що під дією лимонної кислоти збільшуються розміри капілярів всередині целюлозних волокон, які при подальшій обробці заповнюються модифікаторами, продовжуючи термін функціонування захисного текстилю. 
Таблиця 2

Результати розрахунку рівня енергоінформаційного впливу текстильних матеріалів з АМО на функціональний стан організму людини після трьох циклів прання

\begin{tabular}{|c|c|c|c|c|c|c|c|c|}
\hline \multirow{3}{*}{$\begin{array}{c}\text { Види } \\
\text { середовищ } \\
\text { випробо- } \\
\text { вування }\end{array}$} & \multicolumn{6}{|c|}{$\begin{array}{l}\text { Кількість органів людини, } \\
\text { що знаходяться у стані: }\end{array}$} & \multirow{2}{*}{\multicolumn{2}{|c|}{$\begin{array}{l}\text { Коефіціснт } \\
\text { комфортності }\end{array}$}} \\
\hline & \multicolumn{2}{|c|}{$\begin{array}{c}\text { енергетичної } \\
\text { лабільності }\end{array}$} & \multicolumn{2}{|c|}{$\begin{array}{c}\text { енергетичної } \\
\text { нестійкості }\end{array}$} & \multicolumn{2}{|c|}{$\begin{array}{l}\text { енергетичної } \\
\text { недостатності }\end{array}$} & & \\
\hline & $\begin{array}{c}\text { ocoбa } \\
1\end{array}$ & $\begin{array}{c}\text { ocoбa } \\
2\end{array}$ & $\begin{array}{c}\text { ocoбa } \\
1\end{array}$ & $\begin{array}{c}\text { ocoбa } \\
2\end{array}$ & $\begin{array}{c}\text { ocoбa } \\
1\end{array}$ & $\begin{array}{c}\text { ocoбa } \\
2\end{array}$ & $\begin{array}{c}\text { особа } \\
1\end{array}$ & $\begin{array}{c}\text { особа } \\
2\end{array}$ \\
\hline $\mathrm{C} 1$ & 28 & 37 & 25 & 0 & 12 & 28 & 1,00 & 1,00 \\
\hline $\mathrm{C} 2$ & 30 & 37 & 20 & 0 & 15 & 28 & 1,03 & 1,00 \\
\hline C3 & 37 & 45 & 18 & 4 & 10 & 16 & 1,14 & 1,12 \\
\hline $\mathrm{C} 4$ & 45 & 52 & 10 & 13 & 10 & 0 & 1,26 & 1,23 \\
\hline
\end{tabular}

Щоб відслідкувати динаміку зміни коефіцієнту комфортності для різних середовищ випробовування до та після прання побудовано діаграми, представлені на рисунку 2. При визначенні тенденції зміни комфортності контрольний зразок (C2) не враховувався, оскільки не чинить виразного впливу на організм людини.

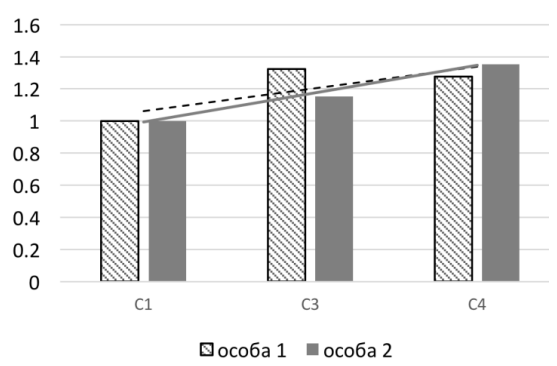

a)

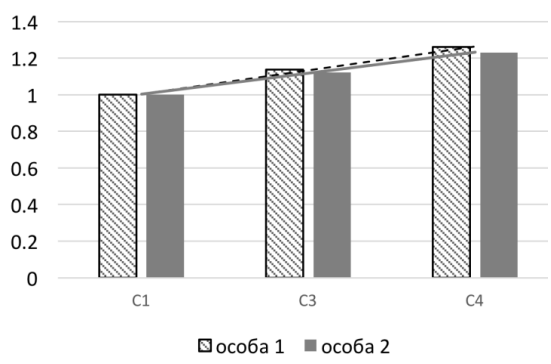

б)

Рис. 2. Динаміка зміни коефіціснта комфортності досліджуваних осіб під впливом зразків модифікованих матеріалів:

$$
\text { а - до прання; б - після прання }
$$


Як видно $з$ діаграм, після модифікації зразків спостерігається тенденція покращення комфортності організму досліджуваних осіб. Ця тенденція зберігається також після трьох циклів прання.

Встановлено, що усі текстильні полотна в середовищах взаємодії 3 людиною С2, С3, C4 здійснюють енергоінформаційний вплив на організм досліджуваних осіб. Ураховуючи призначення цих полотен, важливим $є$ вибір полотна із найвищим коефіцієнтом комфортності для функціонального стану організму досліджуваних осіб (табл. 1, 2). Як бачимо, таким варіантом є зразок, модифікований шляхом просочення текстильного матеріалу лимонною кислотою та наступного розпилення нанорозчину півонії лікарської.

\section{6. Сфери астосування тканин з антимікробними властивостями}

Антимікробні матеріали і вироби на волокнистих носіях широко застосовуються у багатьох сферах життєдіяльності людини i навколишнього середовища. Виробництво антимікробних матеріалів і виробів постійно збільшується, розробляються нові способи їх отримання, в тому числі 3 використанням методів нанотехнологій, відповідно збільшується асортимент антимікробного одягу та текстилю (рис. 3).

\section{7. Висновки}

В роботі здійснений ретроспективний огляд світових досягнень в сфері розробки і використання бактерицидної наномодифікації текстильних матеріалів, в тому числі за «зеленою» технологією. Визначені найбільш ефективні способи впровадження нанокомпонентів в структуру текстильних матеріалів.

Запропоновано метод надання антимікробних властивостей текстильним матеріалам 3 використанням розчину настоянки півонії лікарської. Використання рослинної сировини при створенні антимікробного текстилю обумовлено іiі доступністю, а також, в більшості випадків, низькою токсичністю, відсутністю звикання i негативних побічних явищ. Показано необхідність визначення енерго-інформаційного впливу наномодифікаторів на функціонування органів та систем органів людини.

Розроблено методику нанесення фітопрепарату на текстильне полотно. Встановлено, що для стійкого закріплення і рівномірного розподілу наночастинок препарату по поверхні текстильного полотна 
Chapter «Engineering sciences»

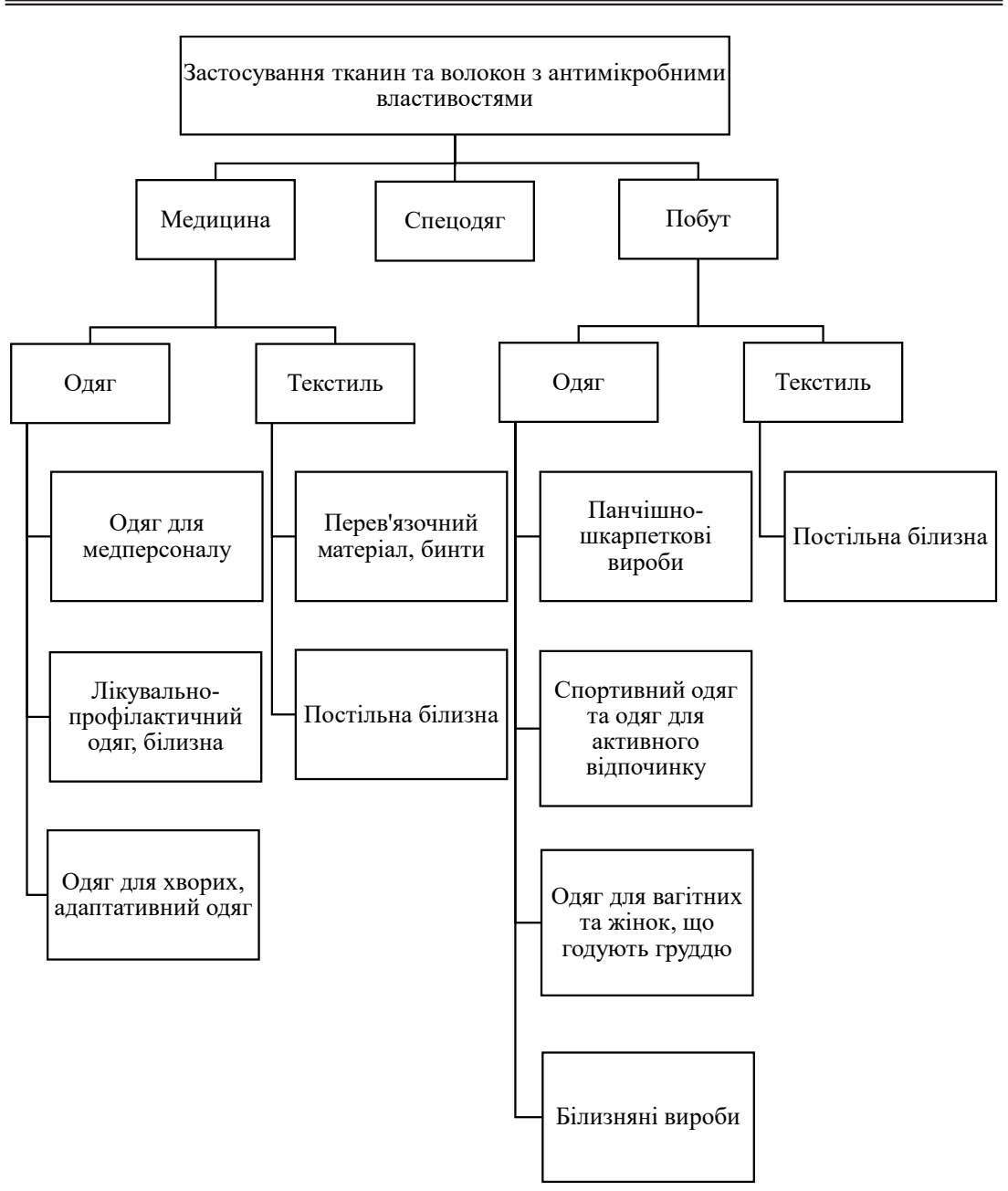

\section{Рис. 3. Застосування тканин та волокон з антимікробними}

доцільно застосовувати метод розпилення розчину та структурного руйнування волокна за допомогою кислот. Цей метод перешкоджає швидкому вимиванню наночастинок 3 поверхні тканини в процесі експлуатації та прання. 
Оскільки текстильні матеріали відіграють важливу роль в формуванні енергетичних потоків системи «людина-одяг-навколишнє середовище» i такий вплив може бути інертним, позитивним або негативним, проведено оцінку енергоінформаційного впливу модифікованих матеріалів на функціональний стан органів та систем органів людини з використанням методу хвильової медицини.

Встановлено, що отримані в результаті модифікації розчином півонії лікарської матеріали здійснюють позитивний вплив на енергетичний стан людини та активують процеси в організмі, які відповідають за імунну систему. Це дає можливість вважати, що ці матеріали активно захищають організм від впливу патогенної мікрофлори.

Також завдяки методу енергоінформаційної діагностики визначено стійкість до прання досягнутого в результаті модифікації антимікробного ефекту. Після трьох циклів прання зразки, модифіковані лимонною кислотою з розчином півонії чинять більш активну дію на організм досліджуваних осіб, в порівнянні із зразками модифікованими лише розчином півонії.

Отже, отримані в роботі результати сприяють поширенню використання “зелених технологій” для виготовлення текстильних матеріалів з антимікробними властивостями.

\section{Список літератури:}

1. Разуваев А.В. Современныегигиенические нормы и антимикробная отделка текстильных материалов. Текстильная промылиленность. 2010. № 4. С. 24-26.

2. Пехташева Е.Л., Неверов А.Н., Заиков Г.Е., Шевцова С.А., Темникова Н.Е. Способы защиты материалов от биоповреждений. Вестник казанского технологического университета. 2012. № 20. С. 167-172.

3. Халиуллина М.К., Гадельшина Э.А. Использование различных бактерицидных и фунгицидных добавок в полимерах при производстве антимикробных текстильных материалов. Вестник технологического университета. 2014. T. 17. № 8. C. 87-91.

4. Gratiela G. Pircalabioru, Mariana-Carmen Chiriuc. Nanoparticulate drugdelivery systems for fighting microbial biofilms: from bench to bedside. Future Microbiol. 2020. № 15(8)7. P. 679-698.

5. Матвейцова Д.С., Параска О.А., Карван С.А. Розробка композицій на основі наночастинок для кінцевої обробки текстильних матеріалів. ВосточноЕвропейский журнал передовых технологий. 2016. № 5. С. 19-25.

6. Georgios A. Sotiriou and Sotiris E. Pratsinis. Antibacterial Activity of Nanosilver Ions and Particles. Environmental Science \& Technology. 2010. Vol. 44(14). P. 5649-5654. DOI: 10.1021/es101072s 
7. Супотницкий М.В. Механизмы развития резистентности к антибиотикам у бактерий. Биопрепараты. 2011. № 2. С. 44.

8. Дымникова Н.С., Ерохина Е.В., Морыганов А.П. Лубяные волокна новые возможности для «зеленой» нанотехнологии. Российский химический журнал (Ж. Рос. хим. об-ва им. Д.И. Менделеева). 2020. T. LXIV, № 1. C. 23-31.

9. Bereznenko N.P., Bereznenko S.M., Pawłowa M., Jancałowskij O.I., Vlasenko V.I. Influence of Textile Materials on the Functional State of Human Body. Towaroznawcze Problemy Jakosci. 2011. No. 4. P. 59-65.

10.Патент на корисну модель № 88422, МПК А61К 35/00. Антимікробний лікарський засіб / Кисличенко В. С., Журавель І. О., Бурда Н. С., Сахацька I.M. (Україна). - № u 2013 13030; Заявл. 08.11.2013; Опубл. 11.03.2014, Бюл. № 5.

11. Ручний відпарювач Steam\&Go. URL: https://www.philips.ua/c-p/ GC361_20/steam-go-handheld-garment-steamer

12. Краснюк Л.В., Троян О.М., Янцаловський О.Й., Тороканець В.С. Перспективи створення багатофункціональних швейних виробів із урахуванням біологічно активних точок та біологічно активних зон тіла людини. Вісник Хмельнищького національного університету. Технічні науки. 2016. № 5. С. 110-115.

13. Пашкіна О.В., Сорока С.О. Спосіб визначення впливу біологічно активних речовин на шкіру. Тези доповідей XVII Міжнародної науково-технічної конференції «Приладобудування: стан і перспективи» (15 травня 2018, м. Київ, НТУ КПІ ім. Ігоря Сікорського). Київ : НТУ КПІ ім. Ігоря Сікорського, 2018. С. 362-365.

14. Buhantsova, L., Luschevska, O., Troyan, O., Krasniuk, L., Yantsalovskyi, O. Formation of the package of materials of adaptive multifunctional clothing. Technology audit and production reserves. 2017. Vol. 3.3(35). P. 4-12.

15.Березненко М.П., Власенко В.І., Янцаловський О.Й. Дослідження впливу текстильних матеріалів на енерго-інформаційний стан організму людини. Сборник научных трудов SWorld. 2014. № 32(4). С. 31-38.

16. Пат. №35944, МПК G01 N33/36. Спосіб оцінки комфортності текстильних матеріалів / О.М. Лущевська, О.Й. Янцаловський, О.М. Троян; заявник і власник патенту Хмельницький націон. ун-т. №200805703; Заявл. 30.04.08; Опубл. 10.10.2008, Бюл. № 19.

\section{References:}

1. Razuvaev A.V. (2010). Sovremennye gigienicheskie normy i antimikrobnaya otdelka tekstil'nykh materialov [Modern hygiene standards and antimicrobial finishing of textile materials]. Textile industry, no. 4, pp. 24-26.

2. Pekhtasheva E.L., Neverov A.N., Zaikov G.E., Shevtsova S.A., Temnikova N.E. (2012). Sposoby zashchity materialov ot biopovrezhdeniy [Methods for protecting materials from bio-damage]. Bulletin of Kazan Technological University, no. 20, pp. 167-172.

3. Khaliullina M.K., Gadel'shina E.A. (2014). Ispol'zovanie razlichnykh bakteritsidnykh i fungitsidnykh dobavok v polimerakh pri proizvodstve antimikrobnykh tekstil'nykh materialov [The use of various bactericidal and fungicidal additives in polymers in the production of antimicrobial textile]. Technological University Bulletin, vol. 17, no. 8, pp. 87-91. 
4. Gratiela G. Pircalabioru, Mariana-Carmen Chiriuc (2020). Nanoparticulate drug-delivery systems for fighting microbial biofilms: from bench to bedside. Future Microbiol, vol. 15(8)7, pp. 679-698.

5. Matvejcova D.S., Paraska O.A., Karvan S.A. (2016). Rozrobka kompozycij na osnovi nanochastynok dlja kincevoji obrobky tekstyljnykh materialiv [Development of compositions based on nanoparticles for final processing of textile materials]. Eastern European Journal of Advanced Technologies, no. 5, pp. 19-25.

6. Georgios A. (2010). Sotiriou and Sotiris E. Pratsinis. Antibacterial Activity of Nanosilver Ions and Particles. Environmental Science \& Technology, vol. 44(14), pp. 5649-5654. DOI: 10.1021/es101072s

7. Supotnitskiy M.V. (2011). Mekhanizmy razvitiya rezistentnosti k antibiotikam u bakteriy [Mechanisms of the development of antibiotic resistance in bacteria]. Biological, no. 2, p. 44.

8. Dymnikova N.S., Erokhina E.V., Moryganov A.P. (2020). Lubyanye volokna novye vozmozhnosti dlya «zelenoy» nanotekhnologii [Bast fibers - new opportunities for green nanotechnology]. Russian Chemical Journal, vol. LXIV, no. 1, pp. 23-31.

9. Bereznenko N.P., Bereznenko S.M., Pawłowa M., Jancałowskij O.I., Vlasenko V.I. (2011). Influence of Textile Materials on the Functional State of Human Body. Towaroznawcze Problemy Jakosci, vol. 4, pp. 59-65.

10. Patent No. 88422, IPC A61K 35/00. Antimicrobial drug / Kyslychenko V.S., Zhuravelj I.O., Burda N.Je., Sakhacjka I.M.; applicant and patent holder. No. u 2013 13030; Appl. 08.11.2013; Publ.11.03.2014, Bulletin. No. 5.

11. Manual steamer Steam\&Go // Intera-DiaCor. Available at: https://www.philips.ua/c-p/GC361_20/steam-go-handheld-garment-steamer

12.Krasnjuk L.V., Trojan O.M., Jancalovsjkyj O.J., Torokanecj V.S. (2016). Perspektyvy stvorennja baghatofunkcionaljnykh shvejnykh vyrobiv iz urakhuvannjam biologhichno aktyvnykh tochok ta biologhichno aktyvnykh zon tila ljudyny [Prospects for the creation of multifunctional garments, taking into account biologically active points and biologically active areas of the human body]. Bulletin of Khmelnytsky National University. Technical sciences, no. 5, pp. 110-115.

13.Pashkina O.V., Soroka S.O. (2018). Sposib vyznachennja vplyvu biologhichno aktyvnykh rechovyn na shkiru [Method of determining the effect of biologically active substances on the skin]. Proceedings of the XVII International Scientific and Technical Conference "Instrument Making: Status and Prospects" (Kyiv, KPI. Igor Sikorsky, May 15, 2018), Kyiv: KPI. Igor Sikorsky, pp. 362-365.

14. Buhantsova, L., Luschevska, O., Troyan, O., Krasniuk, L., Yantsalovskyi, O. (2017). Formation of the package of materials of adaptive multifunctional clothing. Technology audit and production reserves, vol. 3.3(35), pp. 4-12.

15.Bereznenko M.P., Vlasenko V.I., Jancalovsjkyj O.J. (2014). Doslidzhennja vplyvu tekstyljnykh materialiv na energho-informacijnyj stan orghanizmu ljudyny [Investigation of the influence of textile materials on the energy-information state of the human body]. Collection of scientific works SWorld, vol. 32(4), pp. 31-38.

16.Patent No. 35944, IPC G01N33/36 A method of evaluating the comfort of textile materials, Lucshevska O.M., Yantsalovsky O.Y., Trojan O.M.; applicant and patent holder Khmelnitsky National University - No. 200805703; Appl. 30.04.08; Publ. 10.10.2008, Bulletin. No. 19, p. 4. 